\title{
Variability of aggressiveness and virulence of Phytophthora palmivora influencing the severity of papaya fruit rot in postharvest in Bahia, Brazil
}

\author{
Variabilidad de la agresividad y virulencia de Phytophthora palmivora que \\ influencian la severidad de la pudrición de los frutos de papayo en pos cosecha en \\ Bahia, Brasil
}

\begin{abstract}
Thiago Alves Santos de OLIVEIRA ${ }^{1}$; Luiz Eduardo Bassay BLUM ${ }^{2}$; Elizabeth Amélia Alves DUARTE ${ }^{3}$; Zayda Piedad Morales MOREIRA ${ }^{4}$; Edna Dora Martins Newman LUZ ${ }^{5}$

${ }^{1}$ Autor para la correspondencia - Ingeniero Agrónomo, Ph.D. en Fitopatología, Investigador Científico, Departamento de Fitopatología, Universidad de Brasilia (UnB), Campus Universitario Darcy Ribeiro, CEP: 70910-900, Brasilia, Distrito Federal, Brasil, oliveira.tas@gmail.com

2 Ingeniero Agrónomo, Ph.D. en Fitopatología, Prof. Associado, ${ }^{1}$ Departamento de Fitopatología, Universidad de Brasilia (UnB), Brasilia, Distrito Federal, Brasil. luizblum@unb.br

${ }^{3}$ Biológa, Ph.D. en Genética y Biología Molecular, ${ }^{2}$ Centro de Ciencias Agrícolas, Ambientales y Biológicas, Universidad Federal do Recóncavo da Bahia (UFRB), Cruz das Almas, Bahia, Brasil, elizabethaad@gmail.com

${ }^{4}$ Ingeniera en Biotecnología, Maestría en Microbiología Agrícola, Facultad de Ingeniería y Ciencias Agropecuarias, Universidad de las Américas (UDLA), Quito, Pichincha,Ecuador, moraleszaydap@gmail.com

${ }^{5}$ Ingeniera Agrónoma, Ph.D. en Fitopatología, Investigador Científico, ${ }^{3}$ Sección de Fitopatología, Comissão Executiva do Plano da Lavoura Cacaueira (CEPLAC), Ilhéus, Bahia, Brasil, ednadora@cepec.gov.br
\end{abstract}

Recebido em: 23-07-2014; Aceito em: 29-10-2015

\begin{abstract}
Papaya (Carica papaya L.) is susceptible to various production diseases, therefore, studies are needed to reduce them. Papaya fruit rot (Phytophthora palmivora (Butler) Butler) is one of the fungal diseases present in producing regions (Bahia and Espírito Santo) of Brazil. This study aimed to evaluate the variability of aggressiveness and virulence of Phytophthora palmivora that influence the severity of fruit rot in postharvest in vitro and in vivo. The following mycelial growth characteristics were evaluated: (a) mycelial growth speed index (MGSI); (b) mycelial growth speed potential (\%MGSI); (c) spore production (SP); (d) spore production potential (\%SP) and (e) growth potential (\%GP) of 21 strains. The maximum mycelial growth after 120 hours of cultivation in strains of $P$. palmivora ranged between 27 and $81 \mathrm{~mm}$ for strains 355 and 356, respectively. Strains 356, 363, 839, 1056, 1060 and 1189 showed the highest MGSI values. These strains have a high colonization speed and, therefore, good capacity to settle on the substrate. Among them, strains 356, 1060, 839 and 363 showed better \%MGSI when compared with the other strains. The most virulent were: 356, 357, 358, 359, 361, 363, 839, 1055, 1056, 1057, 1060 and 1189, whereas the most aggressive were 356 and 1060.
\end{abstract}

Additional keywords: mycelial growth; spore production; fungal rot.

\section{Resumen}

El papayo (Carica papaya L.) es susceptible a varias enfermedades que afectan la producción, por lo tanto, es necesario realizar estudios que puedan reducir la presencia de estas. La pudrición de los frutos (Phytophthora palmivora (Butler) Butler) del papayo es una de las enfermedades de etiología fungosa presente en regiones productoras (Bahia e Espírito Santo) de Brasil. El objetivo del presente estudio fue evaluar la variabilidad de la agresividad y virulencia de Phytophthora palmivora que influencian la severidad de la pudrición de los frutos en pos cosecha in vitro e in vivo. Fueron evaluadas las características de crecimiento micelial (a) índice de velocidad de crecimiento micelial (IVCM); (b) potencial de velocidad de crecimiento micelial (\%IVCM); (c) producción de esporas (PE); (d) potencial de producción de esporas (\%PE) y (e) potencial de crecimiento (\%PC) de 21 cepas. El máximo crecimiento micelial después de 120 horas de cultivo en las cepas de $P$. palmivora varió entre 27 y $81 \mathrm{~mm}$ para las cepas 355 y 356, respectivamente. Las cepas 356, 363, 839, 1056, 1060 y 1189 presentaron los valores de IVCM más elevados. Estas cepas tienen una velocidad de colonización alta y por lo tanto una buena capacidad para establecerse en el sustrato. De estas, la 356, 1060, 839 y 363 presentaron mejores \%IVCM al ser comparadas con las otras cepas. Las más virulentas fueron: 356, 357, 358, 359, 361, 363, 839, 1055, 1056, 1057, 1060 y 1189, mientras que las más agresivas 356 y 1060.

Palavras-chave adicionais: crecimiento micelial; producción de esporas; putrefacción fúngica. 


\section{Introduction}

Commercial cultivation of papaya has economic significance in tropical and subtropical regions (Silva, 2001). Brazil is the world's largest producer, with a production of 1.5 million tons per year (IBGE 2013), besides being one of the major exporters, supplying the market of Portugal and United Kingdom (CEPEA, 2015). The southeast and northeast regions totalize, on average, $73 \%$ of Brazilian production, highlighting the states of Bahia and Espírito Santo as the main producers (IBGE, 2013). In addition to the economic importance, papaya cultivation in Brazil represents a significant social factor in generating employment and income (Oliveira et al., 2006).

Papaya is susceptible to various diseases, among which fungal rots caused by Colletotrichum gloeosporioides (Penz.) Penz. \& Sacc., Phoma carica-papaya (Tarr.) Punithalingam, Phytophthora palmivora (Butler) Butler, Stemphylium lycopersici (Enjoji), Geotrichum candidum Link. Ex. Pers., Cladosporium herbarum (Pers.) Linnh ex Gray, among others, are responsible for considerable losses (Silva, 2001, Zambolim et al., 2002, Rezende \& Martins, 2005, Dantas \& Oliveira, 2006).

In Brazil, the first recorded incidence of P. palmivora in papaya was in São Paulo in 1951. There are records of this species in several Brazilian states, such as: Alagoas, Bahia, Ceará, Espírito Santo, Maranhão, Minas Gerais, Pará and Pernambuco (Mendes et al., 1998). Initially, $P$. parasitica (Dastur) isolated from fruits in Hawaii was considered the causative agent of papaya fruit rot (Ko, 1994). Later, it was found that $P$. palmivora (species considered to be polyphagous and cosmopolitan) is one of the main pathogens in pre- and postharvest in papaya (Oniha \& Egwari, 2015), being prevalent in Brazil in number of hosts, in addition to being reported in other crops of economic relevance (Luz \& Matsuoka, 2001). The ability to survive and multiply in various hosts can be considered an evolutionary advantage and ensures long-term persistence skills of the pathogen (Taleb-Hossenkhan \& Ibrahim, 2015).

Like other Oomycetes, $P$. palmivora depends on water both on the ground and on the surface of plants for sporangia formation, zoospore release and dissemination (Luz, 2006). Thus, rain and wind are the main factors of dispersion. Rain spreads the inoculum from a fruit to another, to the floor and then into the air, where it is dispersed by the wind through droplets of water to other plants (Ko, 1994). For this reason, fruit rot is related to rainy periods and heavy soils, excessively wet and poorly drained, where the disease starts when sporangia are spread by the wind on rainy days and reach the surface of the fruits (Silva, 2001). Several factors related to the fruit, pathogen, weather and conditions in postharvest determine the incidence and severity of the diseases (Eckert, 1993, Day \& Shattock,1997, Oliveira et al., 2014).

Basic knowledge of postharvest physiology of each pathosystem, as well as of the characteristics of the host, pathogen and environmental conditions that favor disease development, is needed to suggest effective measures to prevent and control it (Oliveira et al., 2006, Oliveira et al., 2014). Additionally, attempts to control post-harvest diseases in fruits, based on limited information on the pathogen, can lead to little or no reduction of the problem and raise the cost of production without substantial increase in the quality of products (Silveira et al., 2001).

Studies on identification, characterization and quantification of pathogens responsible for postharvest diseases in fruits are scarce and nonsystematic. In this context, it has become imperative to conduct this study that aims to study the variability of aggressiveness and virulence of the pathogen influencing the severity of papaya fruit rot in postharvest.

\section{Material and methods}

\section{Strain Collection}

21 strains of $P$. palmivora from the Arnaldo Gomes Medeiros' Phytophthora Collection of Cocoa Research Center (CEPEC) were used (Table 1). Strains were replicated in Petri dishes with PARPH selective medium (Kannwischer \& Mitchell, 1978) and incubated under light for five days at $25 \pm 2{ }^{\circ} \mathrm{C}$. Later, discs $(5 \mathrm{~mm})$ were transferred to dishes containing Carrot Agar medium (CA) and incubated under continuous light at $25 \pm 2{ }^{\circ} \mathrm{C}$ for 9 days. Pathogens were inoculated in healthy fruits at ripening stage 2 (Ritzinger \& Souza, 2000) to observe the characteristic symptoms of $P$. palmivora and reisolated in test tubes with $\mathrm{CA}$ medium, following Koch's postulates and preserved by the method of Castellani for further studies.

\section{In vitro and in vivo study on the characteristics of mycelial growth and sporulation of P. palmivora strains of papaya}

\section{Mycelial growth speed Index (MGSI) and poten- tial mycelial growth speed (\%MGSP)}

The modified method of Jackisch-Matsuura \& Menezes (1999) was used to determine the mycelial growth and the growth rate of strains of $P$. palmivora. Each pathogen was grown in 10 Petri dishes with Carrot Agar medium and incubated alternating light (12 hours light / 12 hours dark) at $25 \pm 2{ }^{\circ} \mathrm{C}$ for 10 days.

Radial mycelial growth was quantified 72,96 and 120 hours after being replicated by measuring two opposing diameters, previously marked with a digital gauge ruler, being the results used to calculate the MGSI using the Equation (1), and growth

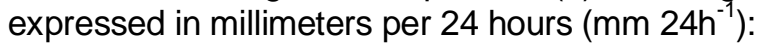


$M G S I=\left[\left(D^{72 h}-0\right)+\left(D^{96 h}-D^{72 h}\right)+\left(D^{120 h}-D^{96 h}\right)\right] / 3$

Wherein:

MGSI = Mycelial Growth Speed Index;

$D^{72 h}=$ Average diameter $(\mathrm{mm})$ in $72 \mathrm{~h}$ of incubation;

$D^{96 \mathrm{~h}}=$ Average diameter $(\mathrm{mm})$ in $96 \mathrm{~h}$ of incubation;

$\mathrm{D}^{120 \mathrm{~h}}=$ Average diameter $(\mathrm{mm})$ in $120 \mathrm{~h}$ of incubation .

Individual MGSI potentials (\% MGSP) of each strain of $P$. palmivora were determined taking as $100 \%$ the highest value of average MGSI found. Strains of $P$. palmivora used had their mycelial growth abilities evaluated to determine which strains were faster in colonizing the environment.

Table 1 - Used strains of Phytophthora palmivora from the Arnaldo Gomes Medeiros' Phytophthora Collection, Department of Plant Pathology of Cocoa Research Center (CEPEC).

\begin{tabular}{ccl}
\hline Reference & Host/substrate & Place of collection \\
\hline 245 & Fruit & Itabuna-BA \\
250 & Fruit & Eunápolis-BA \\
355 & Root & Mucuri-BA \\
356 & Root & Mucuri-BA \\
357 & Root & Mucuri-BA \\
358 & Seedlings & Mucuri-BA \\
359 & Fruit & Mucuri-BA \\
360 & Root & Itabela-BA \\
361 & Root & Itamarajú-BA \\
362 & Root & Itamarajú-BA \\
363 & Root & Itamarajú-BA \\
364 & Soil & Itamarajú-BA \\
365 & Seedlings & Itabela-BA \\
839 & Fruit & Roraima-RO \\
847 & Fruit & Linhares-ES \\
848 & Soil & Linhares-ES \\
1055 & Soil & Eunápolis-BA \\
1056 & Soil & Eunápolis-BA \\
1057 & Soil & Nova Viçosa-BA \\
1060 & Soil & Prado-BA \\
1189 & Soil & Itabuna-BA \\
\hline
\end{tabular}

Spore production (SP) and spore production potential (\%SP)

10 Petri dishes were used for each strain for the evaluation of the pathogen spores concentration (zoospores $\mathrm{mL}^{-1}$ ). After 10 days of growth under the conditions mentioned above, $8 \mathrm{~mL}$ of freezing and sterile distilled water were added on the surface of the medium.

Dishes were kept at $5 \pm 2{ }^{\circ} \mathrm{C}$ for 20 minutes to release zoospores and concentration was estimated at Neubauer chamber after cessation of zoospores with $20 \mu \mathrm{L}$ of FAA fixative solution (formalin, alcohol and acetic acid). The individual SP potential (\%SP) of the evaluated strains of $P$. palmivora was determined considering as $100 \%$ the highest average value of SP found.

\section{Growth potential (\%GP)}

Growth potential of strains of $P$. palmivora was determined by the arithmetic mean of their individual percentages of mycelial growth speed (\%MGSP) and percentages of individual sporulation potentials (\%SP) using the formula:

$\% \mathrm{GP}=(\% \mathrm{MGSI}+\% \mathrm{SP}) / 2$

\section{Evaluation of aggressiveness and virulence through the injured area and AUDPC}

'Sunrise Solo' variety of papaya in stage 2 of maturation was used for the evaluation of aggressiveness and virulence (Ritzinger \& Souza, 2000). After being washed with detergent, disinfected with sodium hypochlorite (1\%) and dried at room temperature, papayas were inoculated in the equatorial region of the fruit with filter paper discs containing a suspension of $5 \times 10^{5}$ zoospores $\mathrm{mL}^{-1}$ of $P$. palmivora. The negative control was inoculated with a suspension of sterile distilled water.

Evaluation of virulence is the relative measure that indicates the amount of disease a strain of a pathogen causes in the host, which was determined by the measurement of the lesion area stipulated in $4000 \mathrm{~mm}^{2}$ and by the area under the disease progress curve (AUDPC) specified in 5500. Evaluation of aggressiveness was determined by the ability a strain with the same virulence has to cause similar amount of disease in less time (Nelson, 1973).

\section{Experiment conduction and statistical analysis}

The experiments were conducted at a temperature of $25 \pm 2{ }^{\circ} \mathrm{C}$, relative humidity of $70 \pm 5 \%$ controlled with a Datalogger $\left(\mathrm{HOBO}{ }^{\circledR}\right)$ sensor. These tests were repeated twice in two different periods.

After two days of incubation, the humid chamber was removed and the lesion area caused by phytopathogens was measured from diameters in two opposite directions for five days every 24 hours. It was measured with the aid of a digital gauge ruler and applying the formula:

$\mathrm{S}=(\pi \times \mathrm{D} 1 \times \mathrm{D} 2) / 4$

Being: $\mathrm{S}=$ colony area; $\mathrm{D} 1=$ diameter $1 ; \mathrm{D} 2=$ diameter 2.

The area under the disease progress curve (AUDPC) was calculated by the expression:

$A U D P C=\{S[(y i+y i+1) / 2] .(t i+1-t i)\}$

Wherein: yi and yi + 1 corresponded to the lesion area values obtained in the two consecutive evaluations, and $t i+1-t i$ is the time interval between the evaluations.

Entirely randomized statistical delineation was used in all experiments. For the analysis of variance, data were submitted to the separation of means performed by the Scott-Knott test $(p \leq 0.05)$ using the SISVAR 5.3 program (Ferreira, 2011). 


\section{Results and discussions}

In vitro study on the characteristics of mycelial growth and sporulation of strains of $P$. palmivora

Mycelial growth speed index (MGSI) and mycelial growth speed potential (\%MGSP)

Maximum mycelial growth at 120 hours of cultivation, obtained by the evaluated strains of
$P$. palmivora, ranged between $27.72 \mathrm{~mm}$ for strain 355 and $81.62 \mathrm{~mm}$ for strain 356 (Table 2). Strains

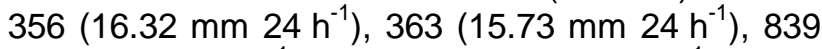

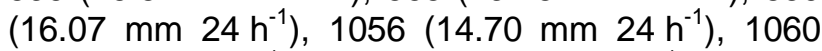

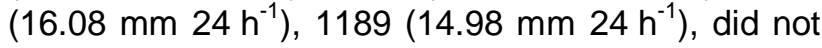
differ statistically from each other but differed from others.

Table 2 - In vitro mycelial growth speed index (MGSI) of Phytophthora palmivora.

\begin{tabular}{|c|c|c|c|c|}
\hline \multirow{2}{*}{ Strains } & \multicolumn{3}{|c|}{ Average diameter of colonies $(\mathrm{mm})$} & \multirow{2}{*}{ 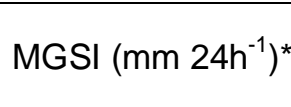 } \\
\hline & Cultivation $72 \mathrm{~h}$ & Cultivation $96 \mathrm{~h}$ & Cultivation $120 \mathrm{~h}$ & \\
\hline 355 & 16.62 & 22.17 & 27.72 & $5.54 \mathrm{a}$ \\
\hline 364 & 17.78 & 23.71 & 29.64 & $5.92 \mathrm{~b}$ \\
\hline 245 & 21.82 & 29.10 & 36.37 & $7.27 \mathrm{~b}$ \\
\hline 365 & 21.95 & 29.27 & 36.59 & $7.31 \mathrm{~b}$ \\
\hline 362 & 24.09 & 32.13 & 40.16 & $8.03 \mathrm{~b}$ \\
\hline 360 & 27.27 & 36.38 & 45.48 & $9.09 \mathrm{~b}$ \\
\hline 250 & 35.20 & 46.80 & 58.50 & $11.70 \mathrm{c}$ \\
\hline 847 & 37.02 & 49.37 & 61.71 & $12.34 \mathrm{c}$ \\
\hline 848 & 38.49 & 51.32 & 64.15 & $12.83 \mathrm{c}$ \\
\hline 359 & 39.23 & 52.31 & 65.39 & $13.07 \mathrm{c}$ \\
\hline 1057 & 39.82 & 53.10 & 66.37 & $13.27 \mathrm{c}$ \\
\hline 357 & 40.59 & 54.12 & 67.65 & $13.53 \mathrm{c}$ \\
\hline 1055 & 42.24 & 56.32 & 70.90 & $13.91 \mathrm{c}$ \\
\hline 358 & 42.17 & 56.23 & 70.29 & $14.05 \mathrm{c}$ \\
\hline 361 & 42.31 & 56.42 & 70.53 & $14.10 \mathrm{c}$ \\
\hline 1056 & 44.11 & 58.82 & 73.52 & $14.70 \mathrm{~d}$ \\
\hline 1189 & 44.94 & 59.93 & 74.91 & $14.98 d$ \\
\hline 363 & 47.19 & 62.92 & 78.65 & $15.73 d$ \\
\hline 839 & 48.22 & 64.30 & 80.37 & $16.07 \mathrm{~d}$ \\
\hline 1060 & 48.23 & 64.31 & 80.38 & $16.08 d$ \\
\hline 356 & 48.97 & 65.30 & 81.62 & $16.32 \mathrm{~d}$ \\
\hline CV (\%) & & & & 11.19 \\
\hline
\end{tabular}

${ }^{*}$ Results represent the means of 10 repetitions. Means followed by the same letter are not statistically different by the Scott-Knott test $(p \leq 0.05)$.

Therefore, these strains showed the highest colonization speed in the medium, and good ability to be established in the substrate. For strains 356 and 1060 , mycelial growth of highly cottony aspect was observed. Whereas the cultivation medium affects the mycelial growth of fungi, the difference in the growth rate of the strains may be related to the influence of microorganisms on the metabolism of nutrients present in CA medium with different speeds and, thereby, affect the synthesis of essential macromolecules on growth (Griffin, 1994). The results of MGSI (Table 2) were transformed into percentages to obtain the mycelial growth speed potential (\%MGSP) of evaluated strains, being considered as $100 \%$ the highest value presented by strain 356 , and the percentage values of the other strains were later calculated. Strains of $P$. palmivora 356, 1060, 839 and 363 did not differ from each other, showing optimal \%MGSP when compared with the other strains (Figure 1A)

\section{Spore production (SP) and spore production potential (\%SP)}

The results of spore production in Petri dishes (Table 3$)$ showed strains $356\left(5.32 \times 10^{6}\right.$ zoospores $\left.\mathrm{mL}^{-1}\right), 358\left(4.03 \times 10^{6}\right.$ zoospores $\left.\mathrm{mL}^{-1}\right)$, $363\left(4.91 \times 10^{6}\right.$ zoospores $\left.\mathrm{mL}^{-1}\right), 1055\left(4.31 \times 10^{6}\right.$ zoospores $\left.\mathrm{mL}^{-1}\right), 1056\left(4.72 \times 10^{6}\right.$ zoospores $\left.\mathrm{mL}^{-1}\right)$, $1060\left(5.81 \times 10^{6}\right.$ zoospores $\left.\mathrm{mL}^{-1}\right)$ and $1189(4.63 \mathrm{x}$ $10^{6}$ zoospores $\mathrm{mL}^{-1}$ ) had higher spore production, differing from the other strains. 

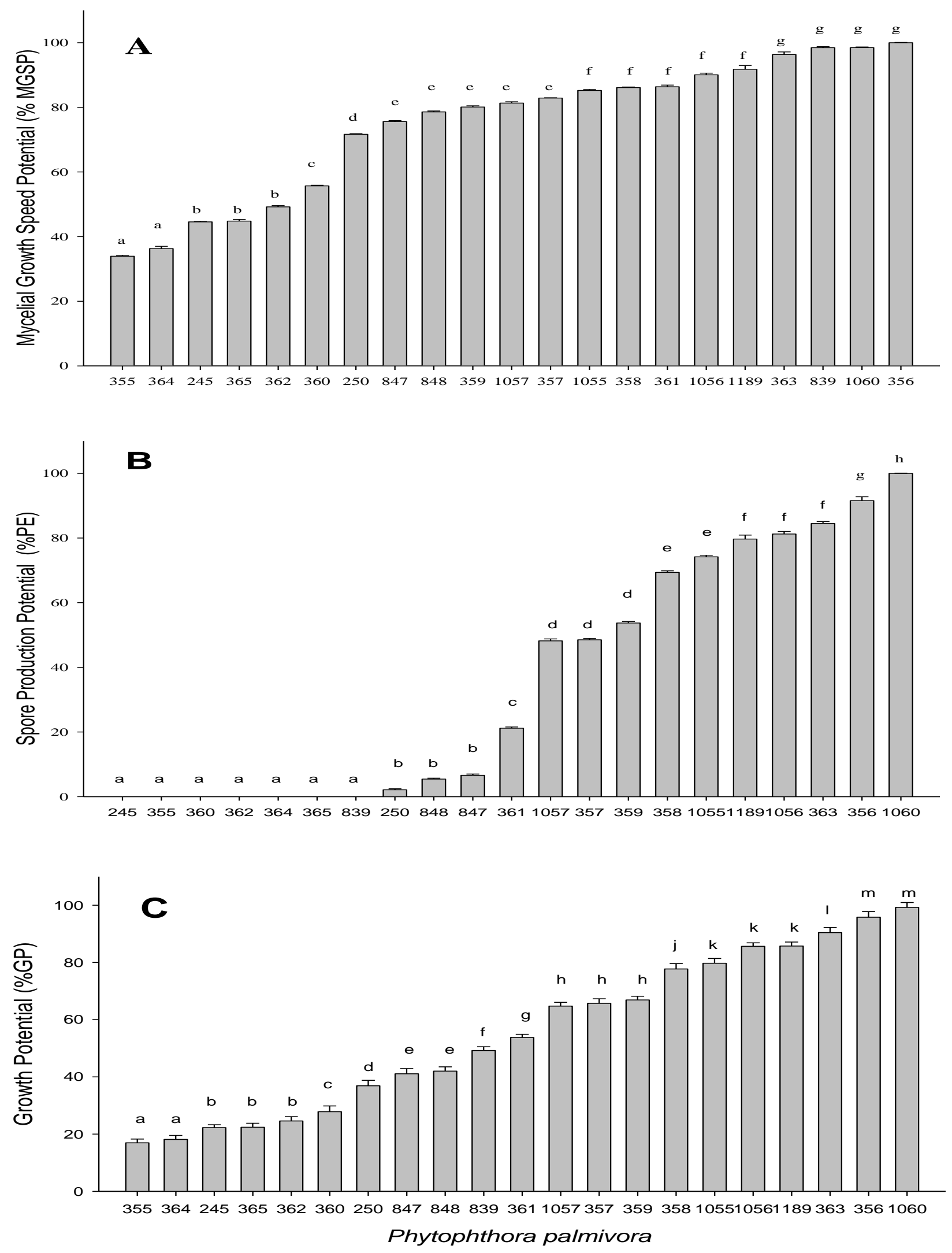

Figure 1 - In vitro studies on the potentials of strains of Phytophthora palmivora. A) Mycelial Growth Speed Potential (\%MGSP); B) Spore Production Potential (\%SP); C) Growth Potential (\%GP). Means followed by the same letter are not statistically different from each other by the Scott-Knott test $(p \leq 0.05)$. 
Table 3 - In vitro spore production (SP) of Phytophthora palmivora.

\begin{tabular}{cc}
\hline Strains & $\begin{array}{c}\text { SP } \\
\text { (Zoospore concentration } \mathrm{mL}^{-1} \text { ) }\end{array}$ \\
\hline 245 & $-\mathrm{a}^{*}$ \\
355 & $-\mathrm{a}$ \\
360 & $-\mathrm{a}$ \\
362 & $-\mathrm{a}$ \\
364 & $-\mathrm{a}$ \\
365 & $-\mathrm{a}$ \\
839 & $-\mathrm{a}$ \\
250 & $1.24 \times 10^{5} \mathrm{a}$ \\
361 & $1.23 \times 10^{6} \mathrm{a}$ \\
848 & $3.16 \times 10^{5} \mathrm{a}$ \\
1057 & $2.80 \times 10^{6} \mathrm{~b}$ \\
357 & $2.82 \times 10^{6} \mathrm{~b}$ \\
847 & $3.83 \times 10^{5} \mathrm{a}$ \\
359 & $3.12 \times 10^{6} \mathrm{a}$ \\
358 & $4.03 \times 10^{6} \mathrm{c}$ \\
1055 & $4.31 \times 10^{6} \mathrm{c}$ \\
1189 & $4.63 \times 10^{6} \mathrm{c}$ \\
1056 & $4.72 \times 10^{6} \mathrm{c}$ \\
363 & $4.91 \times 10^{6} \mathrm{c}$ \\
356 & $5.32 \times 10^{6} \mathrm{c}$ \\
1060 & $5.81 \times 10^{6} \mathrm{c}$ \\
\hline $\mathrm{CV}(\%)$ & 14.63 \\
\hline
\end{tabular}

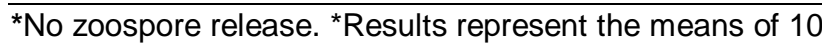
repetitions. Means followed by the same letter are not statistically different by the Scott-Knott test $(p \leq 0.05)$.

Strains 245, 355, 360, 362, 364, 365 and 839 did not release zoospores under the cultivation conditions used in this study (Table 3). Strains 356, 1056, 1060 and 1189 showed better mycelial growth and better sporulation when compared with the other strains.

Variation in the mycelial growth speed potential and spore production potential was observed, possibly because strains were adapted to their respective places of collection (Figure 1B). Monteiro et al., (2004) also observed, for the same strains, differences in preferential temperatures of sporulation. In addition, sporulation is affected by cultivation conditions, such as carbon source, light, mycelium lesions (Casas-Flores et al., 2004), nitrogen source and pH (Steyaert et al., 2010).

\section{Growth potential (\%GP)}

The association of mycelial growth speed potentials (\%MGSI) and sporulation potential (\%SP) resulted in the Spore Production Potential (\%SP); of the evaluated strains (\%GP). Strains 1060 and 356 had higher \%GP and differed statistically from the others (Figure 1C). Strains with higher \%GP would possibly have greater ability to colonize the fruit in the field, for presenting good mycelial growth and sporulation (Figure 1C).

From the results presented in Figure 1, if one of the strains evaluated for their mycelial growth potential was selected, strains 356, 363, 839 and 1060 would be the most aggressive, for presenting a certain total growth in less time in relation to the other strains. However, considering the sporulation capacity, strain 1060 would be the most aggressive. In the set of characteristics (Figure 1), strains 356 and 1060 were the most aggressive regarding the in vitro study. It was also observed that, despite having very fast mycelial growth, strain 839 does not produce spores.

In vivo study on the characteristics of mycelial growth and sporulation of strains of $P$. palmivora in papaya

\section{Mycelial growth speed index (MGSI) and mycelial growth speed potential (\%MGSP)}

Maximum mycelial growth at 120 hours of in vivo cultivation obtained by the evaluated strains of $P$. palmivora ranged between $31.43 \mathrm{~mm}$ for strain 362 and $71.46 \mathrm{~mm}$ for strain 356 (Table 4). Strain 356 showed the highest mycelial growth speed index, differing from the others. It also showed high speed of colonization in the fruit when compared with the others, proven by the fast development in cultivation medium and in papaya.

It is relevant to note that strains 356 and 1060 showed mycelial growth of highly cottony aspect when growing in Carrot Agar and in the fruit. The results of MGSI (Table 4) were transformed into percentages to obtain the mycelial growth speed potential (\% MGSP) of evaluated strains, being considered as $100 \%$ the value presented by strain 356 and the percentage values of the other strains were later calculated.

\section{Spore production (SP) and spore production potential (\%SP)}

The results of spore production in papaya (Table 5) showed strain 356 had the highest production, when compared with the others. Strains 356 and 1060 stand out when compared with the other strains regarding the mycelial growth speed and sporulation both in vivo and in vitro. Pathogen sporulation is an important component in its aggressiveness. If an individual in a population sporulates abundantly, it will have the opportunity to establish its genes in the population (Lebreton et al., 1999, Suassuna et al 2004, Revelo et al., 2011). High levels of sporulation are normally found in pathogenic fungi inoculated in its original host, fitness characteristic in field and ability to spread through the population of the host. The high sporulation capacity of oomycete Phytopathora sp. is a typical characteristic of polycyclic diseases (Lebreton et al., 1999).

There was no zoospore release from strains 362 and 364 both in cultivation conditions and in vitro. To obtain percentage indices expressing the spore production potentials (\%SP) in the dish, the value presented by strain 356 was considered as $100 \%$ and the percentage values of the other strains were calculated later. 
Table 4 - In vivo mycelial growth speed index (MGSI) of Phytophthora palmivora.

\begin{tabular}{|c|c|c|c|c|}
\hline \multirow{2}{*}{ Strains } & \multicolumn{3}{|c|}{ Diameter of colonies (mm) } & \multirow{2}{*}{ 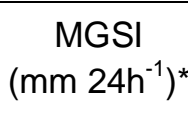 } \\
\hline & Cultivation $72 \mathrm{~h}$ & Cultivation $96 \mathrm{~h}$ & Cultivation $120 \mathrm{~h}$ & \\
\hline 362 & 10.48 & 20.95 & 31.43 & $3.50 \mathrm{a}$ \\
\hline 364 & 11.15 & 22.29 & 33.44 & $3.71 \mathrm{a}$ \\
\hline 360 & 11.40 & 22.81 & 34.21 & $3.80 \mathrm{a}$ \\
\hline 365 & 11.42 & 22.83 & 34.25 & $3.80 \mathrm{a}$ \\
\hline 245 & 11.98 & 23.96 & 35.94 & $3.99 \mathrm{a}$ \\
\hline 355 & 12.46 & 24.92 & 37.38 & $4.15 \mathrm{a}$ \\
\hline 250 & 14.57 & 29.15 & 43.72 & $4.85 \mathrm{~b}$ \\
\hline 847 & 15.84 & 31.68 & 47.52 & $5.27 c$ \\
\hline 848 & 16.46 & 32.91 & 49.37 & $5.48 \mathrm{c}$ \\
\hline 358 & 17.63 & 35.26 & 52.90 & $5.87 d$ \\
\hline 359 & 17.94 & 35.88 & 53.82 & $5.97 d$ \\
\hline 839 & 18.17 & 36.34 & 54.51 & $6.05 d$ \\
\hline 1057 & 18.80 & 37.60 & 56.40 & $6.26 \mathrm{e}$ \\
\hline 357 & 19.04 & 38.07 & 57.11 & $6.34 \mathrm{e}$ \\
\hline 1189 & 19.38 & 38.76 & 58.13 & $6.45 \mathrm{e}$ \\
\hline 1055 & 19.56 & 39.11 & 58.67 & $6.51 \mathrm{e}$ \\
\hline 361 & 19.70 & 39.40 & 59.10 & $6.56 \mathrm{e}$ \\
\hline 1056 & 19.97 & 39.94 & 59.91 & $6.65 \mathrm{e}$ \\
\hline 363 & 21.32 & 42.65 & 63.97 & $7.10 \mathrm{f}$ \\
\hline 1060 & 22.04 & 44.07 & 66.11 & $7.34 \mathrm{f}$ \\
\hline 356 & 23.82 & 47.64 & 71.46 & $7.94 \mathrm{~g}$ \\
\hline CV (\%) & & & & 8.32 \\
\hline
\end{tabular}

${ }^{*}$ Results represent the means of ten repetitions. Means followed by the same letter are not statistically different by the ScottKnott test $(p \leq 0.05)$.

Spore production (SP) and spore production potential (\%SP)

The results of spore production in papaya (Table 5) showed strain 356 had the highest production, when compared with the others. Strains 356 and 1060 stand out when compared with the other strains regarding the mycelial growth speed and sporulation both in vivo and in vitro. Pathogen sporulation is an important component in its aggressiveness. If an individual in a population sporulates abundantly, it will have the opportunity to establish its genes in the population (Lebreton et al., 1999, Suassuna et al 2004, Revelo et al., 2011). High levels of sporulation are normally found in pathogenic fungi inoculated in its original host, fitness characteristic in field and ability to spread through the population of the host. The high sporulation capacity of oomycete Phytophthora sp. is a typical characteristic of polycyclic diseases (Lebreton et al., 1999).

There was no zoospore release from strains
362 and 364 both in cultivation conditions and in vitro. To obtain percentage indices expressing the spore production potentials (\%SP) in the dish, the value presented by strain 356 was considered as $100 \%$ and the percentage values of the other strains were calculated later.

\section{Growth potential (\%GP)}

The association of mycelial growth speed potential (\%MGSI) and sporulation potential (\%SP) in vivo resulted in the growth potential of the evaluated strains (\%GP). Results are presented in Figure 6. The highest \%GP was obtained by strain 356 , significantly different from the others $(p \leq 0.05)$.

From the results (Figure 2), if the selection of one of the evaluated strains should be made both for their mycelial growth potential and sporulation capacity, strain 356 would be selected. In the set of characteristics (Figure 2C), strains 356 and 1060 are the most aggressive regarding the in vivo study. 
Table 5 - In vivo spore production (SP) of Phytophthora palmivora.

\begin{tabular}{cc}
\hline Strains & $\begin{array}{c}\mathrm{SP} \\
\left.\text { (Zoospore concentration } \mathrm{mL}^{-1}\right)\end{array}$ \\
\hline 362 & $-\mathrm{a}^{*}$ \\
364 & $-\mathrm{a}$ \\
245 & $7.40 \times 10^{4} \mathrm{a}$ \\
355 & $4.32 \times 10^{5} \mathrm{a}$ \\
1055 & $5.00 \times 10^{5} \mathrm{a}$ \\
363 & $5.20 \times 10^{5} \mathrm{a}$ \\
848 & $7.80 \times 10^{5} \mathrm{a}$ \\
1189 & $9.40 \times 10^{5} \mathrm{a}$ \\
361 & $1.32 \times 10^{6} \mathrm{a}$ \\
250 & $1.46 \times 10^{6} \mathrm{a}$ \\
360 & $2.82 \times 10^{6} \mathrm{a}$ \\
1057 & $3.08 \times 10^{6} \mathrm{a}$ \\
839 & $3.52 \times 10^{6} \mathrm{a}$ \\
1056 & $8.12 \times 10^{6} \mathrm{~b}$ \\
847 & $1.17 \times 10^{7} \mathrm{c}$ \\
359 & $1.20 \times 10^{7} \mathrm{c}$ \\
357 & $1.81 \times 10^{7} \mathrm{~d}$ \\
358 & $3.58 \times 10^{7} \mathrm{e}$ \\
1060 & $5.44 \times 10^{7} \mathrm{f}$ \\
356 & $6.32 \times 10^{7} \mathrm{~g}$ \\
\hline $\mathrm{CV}(\%)$ & 27.56 \\
\hline
\end{tabular}

${ }^{\star}$ No zoospore release. Results represent the means of ten repetitions. Means followed by the same letter are not statistically different by the Scott-Knott test $(p \leq 0.05)$.

The correlation between the mycelial growth and sporulation of strains of $P$. palmivora in papaya in vitro and in vivo by Pearson's correlation coefficient (Table 6) showed the positive correlation of $73.5 \%(p<$ 0.001 ) between the mycelial growth speed index (MGSI) and spore production (SP) in vitro and of $66 \%$ $(p \leq 0.01)$ in vivo.

Regarding the MGSI in vitro and in vivo there was positive correlation of $93 \%(p<0.001)$, and for SP in vitro and in vivo, obtaining correlation values of $70 \%$ $(p \leq 0.01)$. We can say the evaluated strains, regarding the mycelial growth and spore production, developed statistically equally both in cultivation medium (CA) and in the fruit. For MGSI in vivo and SP in vitro, there was significant correlation of $84.6 \%(p<0.001)$ (Table 6$)$.

There are no reports in the literature under these study conditions, whether in the nature of the study or in the characteristics evaluated in this pathosystem.

\section{Evaluation of aggressiveness and virulence through the injured area and AUDPC}

Considering the lesion area stipulated in $4000 \mathrm{~mm}^{2}$ versus time, it was observed that strain 356 was the most aggressive, with a lesion area of $4,008.54 \mathrm{~mm}^{2}$ at 120 hours after inoculation, differing statistically from the other strains (Table 7). Therefore, there was variability of aggressiveness between strains from the same place of collection. This can be explained by external factors, such as soil and climate differences of the regions of origin, or by internal factors, being the differences between species or strains of the same species the result of their genetic characteristics (Ram, 1993, Pereira et al., 2006, Oliveira et al., 2008, Revelo et al., 2011, Majeed et al., 2014).

Strains 356, 357, 358, 359, 361, 363, 839, 1055, 1056, 1057, 1060 and 1189, caused similar severity in the period of 144 hours after inoculation and were the most virulent when compared with the other strains (Table 7). Strain 356 had greater AUDPC, however, the same degree of virulence when compared with the other strains (Table 7).

Therefore, there is variability of virulence and aggressiveness of the pathogen strains, being the most virulent: $356,357,358,359,361,363,839$, 1055, 1056, 1057, 1060 and 1189, and the most aggressive: 356 and 1060. Majeed et al. (2014) also found significant variation between strains from different regions and the same region, highlighting differences in aggressiveness between strains, and a possible range includes the most aggressive and the less aggressive.

Few studies were conducted to understand the development of fruit rot caused by $P$. palmivora since this type of infection is considered of low incidence for this pathosystem. However, in this study, it was observed that the variability of aggressiveness and virulence directly influences the infection and severity of fruit rot and becomes crucial to understanding the disease cycle.

\section{Conclusions}

Higher mycelium growth rate (MGSI) and higher aggressiveness were observed in strains, 356, 363, 839, 1056 and 1060 in vitro.

Strains from the state of Bahia showed a more virulent and more aggressive behavior than the ones from the state of Espírito Santo.

In all studied epidemiological characteristics, strains 356 and 1060 showed higher aggressiveness in vivo. 

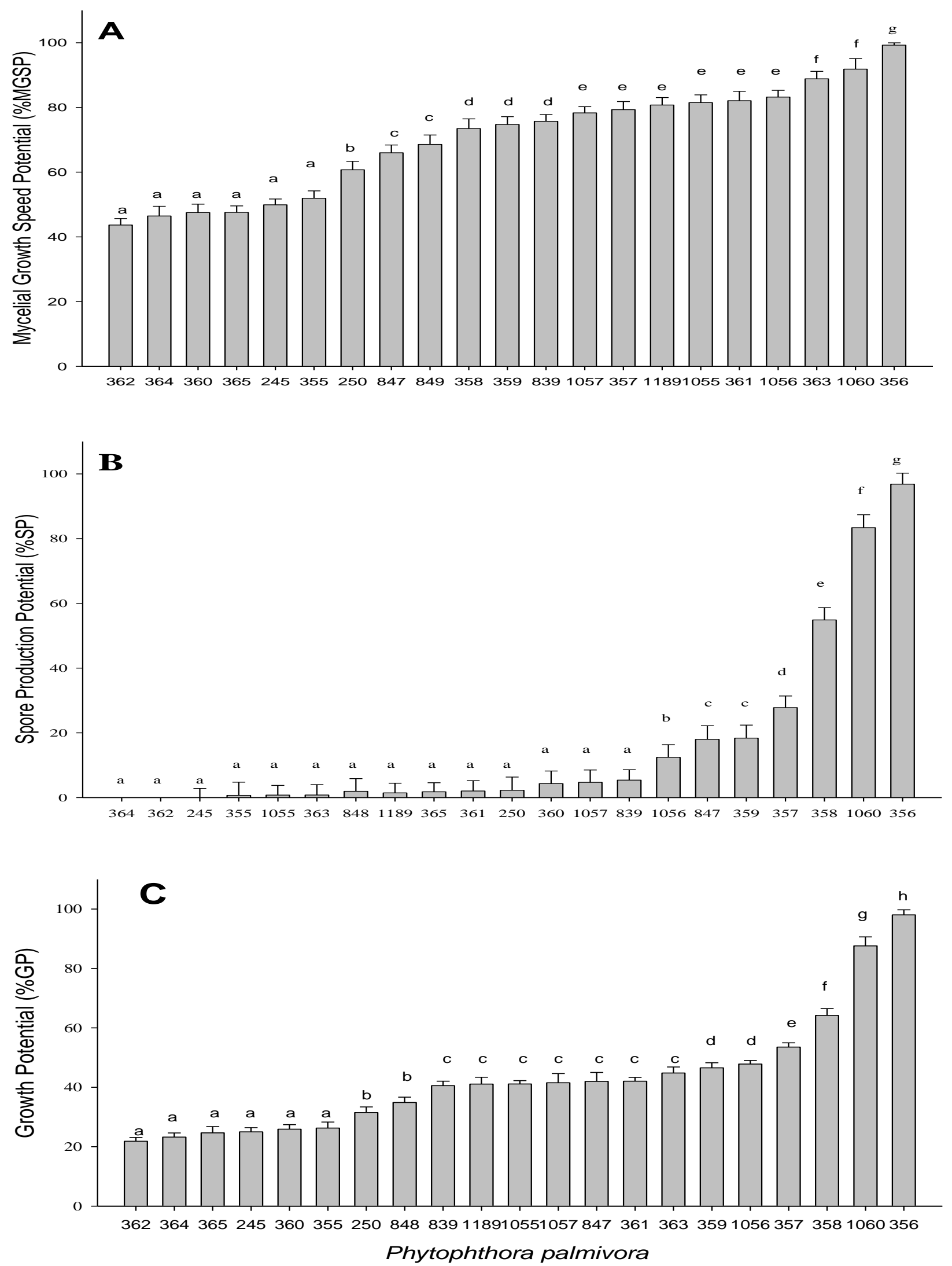

Figure 2 - In vivo studies on the potentials of strains of Phytophthora palmivora. A) Mycelial Growth Speed Potential (\%MGSP); B) Spore Production Potential (\%SP); C) Growth Potential (\%GP). Means followed by the same letter are not statistically different by the Scott-Knott test $(p \leq 0.05)$. 
Table 6 - Correlation Matrix of mycelial growth and sporulation of strains of $P$. palmivora in papaya in vitro and in vivo. In the upper diagonal, correlation between components, and in the lower diagonal, test significance.

\begin{tabular}{|c|c|c|c|c|}
\hline & MGSI (in vitro) & $\mathrm{SP} \times 10^{6}$ (in vitro) & MGSI (in vivo) & $\mathrm{SP} \times 10^{6}$ (in vivo) \\
\hline MGSI (in vitro) & (1) ---- & $0.735^{\mathrm{mx}}$ & $0.930_{x \times x}^{x \times x}$ & $0.472^{x}$ \\
\hline $\mathrm{SP} \times 10^{6}$ (in vitro) & ${ }^{(1)} p<0.001$ & ---- & $0.846^{\operatorname{x\times x}}$ & $0.698^{\star x x}$ \\
\hline MGSI (in vivo) & $p<0.001$ & $p<0.001$ & ---- & $0.660^{x \times}$ \\
\hline $\mathrm{SP} \times 10^{6}$ (in vivo) & $p<0.031$ & $p<0.01$ & $p<0.01$ & ---- \\
\hline
\end{tabular}

MGSI = Mycelial Growth Speed Index; SP = Spore Production; ${ }^{(1)}$ Pearson's Correlation Coefficient; ${ }^{*}$ Significance level of $5 \%$; ${ }^{*}$ Significance level of $1 \%$; ${ }^{* \star *}$ Significance level $<1 \%$.

Table 7 - Evaluation of aggressiveness and virulence through the measurement of the area injured by strains of Phytophthora palmivora and area under disease progress curve (AUDPC).

\begin{tabular}{rrrrrrl}
\hline \multirow{2}{*}{ Strain } & \multicolumn{5}{c}{ Injured Area $\left(\mathrm{mm}^{2}\right)$} & \multirow{2}{*}{ AUDPC } \\
\cline { 2 - 6 } & $48 \mathrm{~h}$ & $72 \mathrm{~h}$ & $96 \mathrm{~h}$ & $120 \mathrm{~h}$ & $144 \mathrm{~h}$ & \\
\hline 362 & $0.00 \mathrm{a}$ & $88.85 \mathrm{a}$ & $355.41 \mathrm{a}$ & $799.68 \mathrm{a}$ & $1,421.66 \mathrm{a}$ & $1,954.78 \mathrm{a}$ \\
364 & $0.00 \mathrm{a}$ & $100.03 \mathrm{a}$ & $400.12 \mathrm{a}$ & $900.27 \mathrm{a}$ & $1,600.48 \mathrm{a}$ & $2,200.67 \mathrm{a}$ \\
365 & $0.00 \mathrm{a}$ & $104.63 \mathrm{a}$ & $418.54 \mathrm{a}$ & $941.71 \mathrm{a}$ & $1,674.16 \mathrm{a}$ & $2,301.97 \mathrm{a}$ \\
360 & $0.00 \mathrm{a}$ & $104.73 \mathrm{a}$ & $418.94 \mathrm{a}$ & $942.61 \mathrm{a}$ & $1,675.76 \mathrm{a}$ & $2,304.17 \mathrm{a}$ \\
245 & $0.00 \mathrm{a}^{(1,2)}$ & $112.84 \mathrm{a}$ & $451.36 \mathrm{a}$ & $1,015.57 \mathrm{a}$ & $1,805.46 \mathrm{a}$ & $2,482.50 \mathrm{a}^{(3)}$ \\
355 & $0.00 \mathrm{a}$ & $125.62 \mathrm{a}$ & $502.505 \mathrm{a}$ & $1,130.63 \mathrm{a}$ & $2,010.01 \mathrm{a}$ & $2,763.77 \mathrm{a}$ \\
250 & $0.00 \mathrm{a}$ & $168.47 \mathrm{~b}$ & $673.91 \mathrm{~b}$ & $1,516.30 \mathrm{~b}$ & $2,695.65 \mathrm{~b}$ & $3,706.52 \mathrm{~b}$ \\
847 & $0.00 \mathrm{a}$ & $197.56 \mathrm{~b}$ & $790.24 \mathrm{~b}$ & $1,778.06 \mathrm{~b}$ & $3,160.99 \mathrm{~b}$ & $4,346.37 \mathrm{~b}$ \\
848 & $0.00 \mathrm{a}$ & $214.70 \mathrm{~b}$ & $858.83 \mathrm{~b}$ & $1,932.36 \mathrm{~b}$ & $3,435.32 \mathrm{~b}$ & $4,723.56 \mathrm{~b}$ \\
358 & $0.00 \mathrm{a}$ & $246.87 \mathrm{c}$ & $987.49 \mathrm{c}$ & $2,221.86 \mathrm{c}$ & $3,949.98 \mathrm{c}$ & $5,431.22 \mathrm{c}$ \\
359 & $0.00 \mathrm{a}$ & $254.42 \mathrm{c}$ & $1,017.70 \mathrm{c}$ & $2,289.82 \mathrm{c}$ & $4,070.80 \mathrm{c}$ & $5,597.35 \mathrm{c}$ \\
839 & $0.00 \mathrm{a}$ & $259.80 \mathrm{c}$ & $1,039.23 \mathrm{c}$ & $2,338.28 \mathrm{c}$ & $4,156.94 \mathrm{c}$ & $5,715.80 \mathrm{c}$ \\
1057 & $0.00 \mathrm{a}$ & $277.72 \mathrm{~d}$ & $1,110.89 \mathrm{~d}$ & $2,499.52 \mathrm{~d}$ & $4,443.59 \mathrm{~d}$ & $6,109.94 \mathrm{~d}$ \\
357 & $0.00 \mathrm{a}$ & $284.79 \mathrm{~d}$ & $1,139.19 \mathrm{~d}$ & $2,563.19 \mathrm{~d}$ & $4,556.79 \mathrm{~d}$ & $6,265.59 \mathrm{~d}$ \\
1189 & $0.00 \mathrm{a}$ & $294.88 \mathrm{~d}$ & $1,179.52 \mathrm{~d}$ & $2,653.92 \mathrm{~d}$ & $4,718.08 \mathrm{~d}$ & $6,487.36 \mathrm{~d}$ \\
1055 & $0.00 \mathrm{a}$ & $300.39 \mathrm{~d}$ & $1,201.56 \mathrm{~d}$ & $2,703.51 \mathrm{~d}$ & $4,806.24 \mathrm{~d}$ & $6,608.58 \mathrm{~d}$ \\
361 & $0.00 \mathrm{a}$ & $305.11 \mathrm{~d}$ & $1,220.47 \mathrm{~d}$ & $2,746.06 \mathrm{~d}$ & $4,881.88 \mathrm{~d}$ & $6,712.59 \mathrm{~d}$ \\
1056 & $91.39 \mathrm{c}$ & $313.59 \mathrm{~d}$ & $1,254.36 \mathrm{~d}$ & $2,822.33 \mathrm{~d}$ & $5,017.47 \mathrm{~d}$ & $6,947.68 \mathrm{~d}$ \\
363 & $78.18 \mathrm{~b}$ & $357.43 \mathrm{e}$ & $1,429.74 \mathrm{e}$ & $3,216.92 \mathrm{e}$ & $5,718.97 \mathrm{e}$ & $7,904.20 \mathrm{e}$ \\
1060 & $103.27 \mathrm{~d}$ & $381.45 \mathrm{e}$ & $1,525.82 \mathrm{e}$ & $3,433.09 \mathrm{e}$ & $6,103.28 \mathrm{e}$ & $8,538.65 \mathrm{e}$ \\
356 & $125.02 \mathrm{e}$ & $445.39 \mathrm{f}$ & $1,781.57 \mathrm{f}$ & $4,008.54 \mathrm{f}$ & $7,126.28 \mathrm{f}$ & $9,865.30 \mathrm{f}$ \\
\hline CV (\%) & 18.93 & 16.65 & 14.32 & 15.87 & 13.75 & 13.79 \\
\hline
\end{tabular}

(1) Means of 10 repetitions; ${ }^{(2)}$ Means followed by the same letter, vertically, are not statistically different from each other by the Scott-Knott test $(p \leq 0.05) ;{ }^{(3)}$ AUDPC = area under disease progress curve calculated based on the lesion areas at $48 \mathrm{~h} ; 72 \mathrm{~h} ; 96 \mathrm{~h} ; 120 \mathrm{~h} ; 144 \mathrm{~h}$ after inoculation.

\section{Acknowledgments}

The authors thank the National Council for Scientific and Technological Development (CNPq) for granting the fellowships, the owner of Granja Alegria for providing the fruit used in this work, the Executive Planning Committee of Cocoa Farming (CEPLAC), the department of logistics and the technicians of the Cocoa Research Center who supported this research.

\section{References}

Casas-Flores S, Rios-Momberg M, Bibbins M, PonceNoyola P, Herrera-Estrella A (2004) BLR-1 and BLR-2, key regulatory elements of photoconidiation and mycelial growth in Trichoderma atroviride. Microbiology 150(11):3561-3569.
CEPEA (2015) Anuário 2015-2015. Availeble in; <http://www.cepea.esalq.usp.br/hfbrasil/edicoes/141/fu II.pdf> (Accesado el10 ago 2015).

Dantas SAF, Oliveira SMA (2006) Doenças do mamão. In: Oliveira SMA, Terao D, Dantas SAF, Tavares, $\mathrm{SCCH}$ (ed) Patologia pós-colheita: Frutas, Olerícolas e Ornamentais Tropicais, Embrapa Informação Tecnológica, p.695-730.

Day JP, Shattock RC (1997) Aggressiveness and other factors relating to displacement of populations of Phytophthora infestans in England and Wales. European Journal of Plant Pathology 103(4):379-391.

Eckert JW (1993) Post-harvest diseases of citrus fruits. Agriculture Outlook 54: 225-232. 
Ferreira DF (2011) Sisvar: a computer statistical analysis system. Ciência e Agrotecnologia 35(6):10391042.

Griffin DH (1994) Fungal physiology. John Wiley \& Sons. 472p.

IBGE - Instituto Brasileiro de Geografia e Estatística (2013). Produção Agrícola Municipal 2012. Rio de Janeiro 39:1-101.

Jackisch-Matsuura AB, Menezes M (1999) Effect of Trichoderma ssp. In the control of Pythium aphanidermatum in tobacco (Nicotiana tabacum). Summa Phytopathologica 25(2)161-164.

Kannwischer ME, Mitchell DJ (1978) The influence of a fungicide on the epidemiology of black shank of tabacco. Phytopathology 68:1760-1765.

Ko WH (1994) Phytophthora fuit rot and root rot. In: Ploetz RC (ed) Compedium of tropical fruit diseases, American Phytopathological Society. p.61-62.

Lebreton L, Lucas JM, Andrivon D (1999) Aggressiveness and competitive fitness of Phytophthora infestans isolates collected from potato and tomato in France. Phytopathology 89(8):679-686.

Luz EDMN (2006) O Gênero Phytophthora no Brasil. In: XXXIX Congresso Brasileiro de Fitopatologia, Fitopatologia Brasileira 31:80.

Luz EDMN, Matsuoka K (2001) Phytophthora: Fungo protista ou Chromista?. In: Luz EDMN, Santos AF, Matsuoka K, Bezerra, JL (ed) Doenças causadas por Phytophthora no Brasil, Livraria e Editora Rural. p.1-21.

Majeed A, Chaudhry Z, Muhammad Z (2014) Variability of the aggressiveness of Phytophthora infestans pathotypes collected from different potato fields of Khyber Pakhtunkhwa (Pakistan). International Journal of Agriculture \& Biology 16(4):807-812.

Mendes MAS, Silva VL, Dianese, JC (1998) Fungos em plantas no Brasil. EMBRAPA/CENARGEN. p. 53-54.

Monteiro AC, Barbosa CC, Correia ACB, Pereira GT (2004) Crescimento e esporulação de isolados de Verticillium lecanii sob diferentes fatores ambientais. Pesquisa Agropecuária Brasileira 39(6):561-565.

Nelson RR (1973) Breeding plants for disease resistance: concepts and applications. Pennsylvania State University Press. 401p.

Oliveira SMA, Terao M, Dantas SAF, Tavares, SCCH (2006) Patologia pós-colheita: frutas, olerícolas e ornamentais tropicais, Brasília, DF: Embrapa informação tecnológica. p.855.

Oliveira TAS, Oliveira, SMA, Michereff SJ, Câmara, MPS, Costa VSO, Lins SRO (2008) Efeito do estádio de maturação, tipo de inóculo e local de inoculação na severidade da podridão peduncular em manga. Tropical Plant Pathology 33:409-414.
Oliveira TAS, Blum LEB, Duarte EAA, Tavares GM, Luz EDMN (2014) Fatores epidemiológicos de Phytophthora palmivora afetando a severidade da podridão-dos-frutos do mamaoeiro na pós-colheita. Summa Phytopathologica 40(3): 256-263.

Oniha M, Egwari L (2015) Fruit, leaf and stem diseases of Carica papaya L. Agriculture \& Food 5: 398-407.

Pereira AL, Silva GS, Ribeiro VQ (2006) Caracterização fisiológica, cultural e patogênica de diferentes isolados de Lasiodiplodia theobromae. Fitopatologia Brasileira 31:572-578.

Ram, C (1993) Características culturais, esporulação e violência do "strain" de Botryodiplodia theobromae, agente causal da queima-das-folhas do coqueiro (Cocos nucifera) Fitopatologia Brasileira 18:143-146.

Revelo E, Dorado G, Lagos LE, Burbano-Figueroa O (2011) Foliar virulence of isolates of Phytophthora infestans sensu lato on detached leaves of two Solanum betaceum cultivars. Tropical Plant Pathology 36(6):367-373.

Rezende JAM, Martins MC (2005) Doenças do mamoeiro. In: Kimati H, Amorim L, Rezende JAM, Bergamin Filho A, Camargo LEA (ed). Manual de fitopatologia: doenças das plantas cultivadas. Ed. Agronômica Ceres Ltda. p.436-443.

Ritzinger CHSP, Souza JS (2000) Mamão: Fitossanidade.EMBRAPA.91p.

Silva GS (2001) Podridão das raízes e dos frutos do mamoeiro. In: Luz, EDMN, Santos AF, Matsuoka K, Bezerra LJ. Doenças causadas por Phytophthora no Brasil. Livraria e Editora Rural. p. 413-432.

Silveira NSS, Michereff SJ, Mariano RLR, Maia LC, Oliveira SMA (2001) Hongos fitopatógenos asociados a frutos comercializados em Recife, Pernambuco. Boletín Micológico, Valparaiso.p. 41-47.

Steyaert JM, Weld RJ, Stewart A (2010) Ambient pH intrinsically influences Trichoderma conidiation and colony morphology. Fungal Biology 114( 2-3):198-208.

Suassuna ND, Maffia LA, Mizubuti ESG (2004) Aggressiveness and host specificity of Brazilian isolates of Phytophthora infestans. Plant Pathology 53:405-413.

Taleb-Hossenkhan N, Ibrahim A (2105) Pathogenic Fitness, Metalaxyl Sensitivity and Isozyme Analysis of Phytophthora infestans Isolates from Mauritius. Plant Pathology Journal 14(3):113-122,

Zambolim L, Do Vale FXR, Monteiro AJA, Costa H (2002) Controle de doenças de plantas: fruteiras. Viçosa. 674p. 